\title{
Update 2020: Management of Non-Small Cell Lung Cancer
}

\author{
Mariam Alexander ${ }^{1} \cdot$ So Yeon $\mathrm{Kim}^{2} \cdot$ Haiying Cheng ${ }^{2} \mathbb{0}$ \\ Received: 26 July 2020 / Accepted: 2 November 2020 / Published online: 11 November 2020 \\ c) Springer Science+Business Media, LLC, part of Springer Nature 2020
}

\begin{abstract}
The past decade has seen a revolution of new advances in the management of non-small cell lung cancer (NSCLC) with remarkable progresses in screening, diagnosis, and treatment. The advances in systemic treatment have been driven primarily by the development of molecularly targeted therapeutics, immune checkpoint inhibitors, and anti-angiogenic agents, all of which have transformed this field with significantly improved patient outcomes. This review will address updates in lung cancer screening, liquid biopsy, and immunotherapy in the front-line setting. We discuss recent advances and highlight the plethora of new approvals of molecular-targeted therapy for subgroups of NSCLC patients with sensitizing EGFR, ALK, ROS1, RET, BRAF V600E, MET, and NTRK alterations.
\end{abstract}

Keywords Lung cancer $\cdot$ Immune checkpoint inhibitors $\cdot$ Targeted therapy

\section{Introduction}

Lung cancer is the second most common cancer and the leading cause of cancer death in the USA. Approximately 247,270 new cases of lung cancer are estimated to occur in 2020 , with 130,340 male cases and 116,930 female cases [1]. Prior studies have reported that lung cancer resulted in more deaths than breast cancer, prostate cancer, colorectal cancer, and leukemia combined in men $\geq 40$ years old and women $\geq 60$ years old. With the introduction of screening guidelines and decrease in tobacco use, the mortality rate for lung cancer has recently decreased by $48 \%$ in males and $23 \%$ in females. Despite this decrease in mortality rate, approximately 140,730 deaths are estimated to be secondary to lung cancer in 2020 [1].

The greatest risk factor for development of lung cancer is tobacco use. Secondhand smoking has also been shown to increase the risk of lung cancer by as much as $26 \%$ [2]. Other risk factors for lung cancer include asbestos exposure, family history of lung cancer, exposure to toxic substances including polycyclic aromatic hydrocarbons, heavy metals,

Haiying Cheng

hcheng@montefiore.org

1 Hollings Cancer Center, Medical University of South Carolina, Charleston, SC, USA

2 Department of Oncology, Montefiore Medical Center, Albert Einstein College of Medicine, Bronx, NY 10461, USA and radon gas [2]. Long-term effects of electronic cigarettes are currently unknown, but mice exposed to electronic cigarettes were more prone to develop lung adenocarcinomas compared to mice exposed to control air [3].

\section{Lung Cancer Screening}

The National Lung Screening Trial (NLST) showed a 20\% reduction in lung cancer mortality with three annual lowdose computed tomography (CT) screenings for patients with high risk for lung cancer at a median follow-up of 6.5 years. Based on these results, the US Preventive Services Task Force (USPSTF) recommends annual screening in patients between the ages of 55 to 80 years with a smoking history of 30 or more pack years, who currently smoke or quit smoking within the past 15 years. Recently, the NELSON (Nederlands-Leuvens Longkanker Screenings Onderzoek) trial showed that the 10-year lung cancer mortality was significantly lower when high-risk patients underwent screening compared to no screening (risk of dying lowered by $24 \%$ in men and $33 \%$ in women) [4]. These trials confirm that low-dose CT screening undoubtedly works in saving lives in a high-risk group with four rounds of screening over 5 years preventing 60 deaths from lung cancer among 6583 screened. These exciting findings are unfortunately not echoed in real-world practice. In a National Health Interview Survey between 2010 and 
2015, of the 6.8 million smokers eligible for lung cancer screening in 2015 , only $3.9 \%$ of them actually received it [5]. This suggests that clinicians and smokers require increased education in the benefits of lung cancer screening for informed decision making.

Lung cancer patients infected with SARS-CoV-2 were recently tracked in the TERAVOLT (Thoracic cancERs international coVid 19 cOLlaboraTion) registry study [6]. Patients with advanced NSCLC were found to have a higher risk of complications and 33\% succumbed to complications from COVID-19. A smoking history was found to be an important predictor of developing complications from COVID-19.

\section{Clinical Presentation and Diagnostic Work-Up}

To date, a majority of lung cancer cases are diagnosed in symptomatic individuals with the most common symptoms being cough, fatigue, dyspnea, chest pain, weight loss, and hemoptysis. Hemoptysis has the highest positive predictive value of $2.4 \%-7.5 \%$ but is a feature of only a fifth of lung cancers [7]. Diagnosis of lung cancer at the earliest stage is strongly associated with improved survival and therefore requires greater readiness by primary care physicians to investigate high risk patients, even when presenting with non-specific symptoms. To diagnose and stage lung cancer, imaging tests (such as CT scans) and tissue/pathologic reviews are required. There are multiple approaches for tissue evaluation, such as bronchoscopy with biopsy or fine needle aspiration (FNA), mediastinoscopy, and thoracentesis. Although the least invasive approach with the highest diagnostic yield is preferred, it is essential to have enough issue for PD-L1 testing and molecular analysis. For centrally located tumors and in patients with adenopathy, EBUS-TBNA has become firstline procedures but for more peripheral pulmonary lesions, image-guided transthoracic core needle biopsy may be preferred. Moreover, patients with a high suspicion of early resectable disease (stage I or II) may not require a biopsy before the surgical procedure.

Staging plays a key role in the selection of therapy based on clinical and pathological factors, which provides a consistency in describing patients in clinical studies and their prognosis. The International Association for the Study of Lung Cancer (IASLC) has developed the lung cancer stage classification based on statistical analysis of an international database of 100,000 patients. The recent 8 th edition of this staging system has been modified to provide a more precise classification based on prognostic analysis of each tumornode-metastasis (TNM) descriptors [8].

\section{Liquid Biopsy}

Liquid biopsy includes testing on a variety of cancer biomarkers, such as circulating tumor DNA (ctDNA), microRNA, and circulating tumor cells (CTCs). Minimally invasive, it can be collected from plasma, serum, urine, CSF, and other resources to determine actionable genomic alterations that may eventually guide therapy and help to assess response. In current clinical practice, tissue diagnosis is still considered the gold standard for initial diagnosis of NSCLC. Moreover, a negative result of liquid biopsy does not rule out the presence of an oncogenic alteration and tissue-based analysis should be further pursued when feasible. At the same time, ctDNA testing can benefit patients who are medically unfit for invasive procedures or when the initial tissue testing is not enough for molecular testing. The non-invasive versus invasive lung evaluation (NILE) study of 282 patients with previously untreated NSCLC showed that there was a $48 \%$ increase in the rate of biomarker detection with ctDNA testing compared to tissue analysis alone with a faster turnaround time [9].

The Guardant360 CDx assay is an FDA-approved liquid biopsy for detection of genomic alterations in patients with any solid tumors, and as a companion diagnostic test to identify $E G F R$ mutations in patients with advanced NSCLC who could benefit from treatment with osimertinib. The FoundationOne Liquid CDx is another FDAapproved comprehensive pan-tumor liquid biopsy test. CtDNA testing has a high specificity $(80 \%-95 \%)$ for $E G F R$ driver mutations but sensitivity varies from $60 \%$ to $85 \%$ [10]. Results from the AURA3 study showed that early clearance of mutations in ctDNA was predictive of outcomes. Plasma samples collected at baseline, at 3 and 6 weeks following treatment with second-line treatment with osimertinib showed that median PFS was longer in patients with clearance of plasma EGFR at 6 weeks (11.1 months, 95\% CI, 8.3-12.6) compared with patients who had detectable mutations (5.7 months, 95\% CI 4.1-7.7). In the AURA2 study, patient's plasma was collected to test for EGFR T790M-resistant mutations with real-time PCR in addition to tissue [11]. There was a higher likelihood of a positive ctDNA in patients with extra-thoracic disease. In the FLAURA3 study, molecular alterations have been identified as a resistance mechanism to first-line osimertinib including $M E T$ amplification, HER2 amplifications, PIK3CA, RAS, and EGFR C797S mutations [12]. ctDNA has also been successfully used for the detection of $A L K / R O S 1$ fusions, BRAF V600E, $R E T$ fusion, and $M E T$ exon 14 skipping mutations. In the BFAST study that screened 2200 patients' plasma, the prevalence of $A L K$ fusions was consistent with tissue testing. For those patients who received alectinib based on 
plasma test results, the response rate was $92 \%$ and 1-year duration of response was $78 \%$ [13]. Most recently, tumor mutation burden (TMB) has been analyzed through a blood-based assay in a subset of the POPLAR and OAK cases [14]. Blood TMB was found to be a predictive biomarker for PFS in patients receiving atezolizumab in NSCLC.

\section{NSCLC Treatment Approaches}

Depending on the stage, histology, genetic alterations, and patient's condition, the treatment approaches in NSCLC usually include surgery, radiotherapy, chemotherapy, immunotherapy, molecularly targeted therapy either alone or in combined modality. Surgical resection with curative intent is recommended for medically fit patients with early stages of NSCLC [Stage I, stage II, and stage IIIA (usually when the involvement of N2 lymph node disease is identified during surgical procedure)]. While adjuvant platinumbased chemotherapy is recommended for stages II-IIIA disease with an absolute decreased risk of death of $5.4 \%$ at 5 years, the relapse rates are high with a relatively high rate of toxicity [15]. Multidisciplinary discussion is recommended prior to treatment, especially for stage IIB and stage IIIA disease. Thus far, molecularly targeted therapies have not demonstrated an overall survival benefit in early-stage patients. Approximately $30 \%$ of patients with NSCLC will have locally advanced disease (T3-T4, N2-N3, stage IIIA-C). Most of the patients with stage III NSCLC are non-surgical candidates and the current standard of care is concurrent chemoradiotherapy followed by immunotherapy [8].

Targeted therapy has improved clinical outcomes in a significant proportion of NSCLC patients with advanced disease. Thus, molecular testing, preferably a broad panelbased approach, is recommended to identify these actionable genetic alterations. Tyrosine kinase inhibitors targeting the EGFR, ALK, ROS1, RET, BRAF V600E, MET Exon 14, and $N T R K$ genetic alterations are now approved for the treatment of several subtypes of NSCLC patients (Table 1). If there are no targetable alterations, PD-L1 expression may assist in making the treatment decision for both squamous and non-squamous NSCLC.

\section{Basics of Molecularly Targeted Therapy in Lung Cancer}

In the advanced setting, molecular testing should be conducted at the time of diagnosis. Approximately 10\%-30\% of NSCLC tumors harbor activating mutations in the tyrosine kinase domain of the EGFR gene, with the incidence increasing up to $60 \%$ in Asians [16]. In patients with metastatic NSCLC harboring sensitizing EGFR mutations, the preferred front-line therapy is osimertinib, a third-generation EGFR TKI, based on the FLAURA study [17]. In this pivotal study, osimertinib was compared to the first-generation TKIs in patients with EGFR-mutated NSCLC and resulted in a superior median OS of 38.6 months for osimertinib versus 31.8 months for the comparator (HR $0.799, p-0.0462$ ). Of note, there was also improved CNS control. Another recently approved option is the combination of the VEGF inhibitor, ramucirumab with erlotinib (a first-generation TKI) in the first-line setting in EGFR-mutated lung cancer (median PFS 19.4 months with the combination compared to 12.4 months, HR $0.59,95 \%$ CI $0.46-0.76, p<0.0001$ ) [18]. Other FDAapproved options in the first-line setting include dacomitinib, afatinib, erlotinib, and gefitinib (Table 1). Multiple studies are currently studying the addition of chemotherapy to TKIs to improve survival in this patient population.

Approximately 5\% of NSCLC tumors harbor ALK gene rearrangements. The phase 3 ALEX trial comparing alectinib (a second-generation ALK TKI) to crizotinib (a firstgeneration ALK TKI) showed a dramatic improvement in PFS (35 months vs. 11 months, HR 0.43), a remarkable control of CNS progression (HR 0.16, 95\% CI 0.10-0.28), and lower toxicities [19]. Similarly, another option in the first-line setting for $A L K$-positive NSCLC is brigatinib. The recent ALTA 1L trial compared brigatinib to crizotinib and showed an improved median PFS (24 months vs. 11 months, HR 0.49 , 95\% CI 0.35-0.68, $p<0.0001$ ) [20]. Other FDAapproved front-line options include crizotinib and ceritinib (Table 1). Upon progression, lorlatinib, other $A L K$ TKIs and chemoimmunotherapy are options.

ROS 1 rearrangement acts as an oncogenic driver in $1 \%-2 \%$ of NSCLC. There is a high degree of homology between the $A L K$ and $R O S$ tyrosine kinase domains. These ROS1-positive tumors are highly sensitive to the TKI ceritinib [21], crizotinib [22], and entrectinib [23]. Upon progression, lorlatinib is an option [24].

RET gene arrangements have been identified in $1 \%-2 \%$ of NSCLC. The recent LIBRETTO-001 trial showed that selpercatinib/LOXO-292 has efficacy in patients with $R E T$ fusion-positive NSCLC [Overall response rate (ORR) 85\%] with responses lasting 6 months or longer in patients who have never received systemic treatment [25]. Once they have progressed, cabozantinib has been shown to have efficacy (median PFS 5.5 months, median OS 9.9 months in 25 patients in a phase II trial) [26].

BRAF V600E mutations are found in 1\%-3\% of NSCLC and are candidates for the combination $B R A F$ inhibitors, dabrafenib in combination with trametinib after progression on chemotherapy [Disease control rate (DCR) 79\%, ORR of $63 \%$ ] [27].

NTRK gene fusions are found in around $0.2 \%$ of NSCLC for which both entrectinib and larotrectinib are the treatment options as either front-line or subsequent lines [28]. 


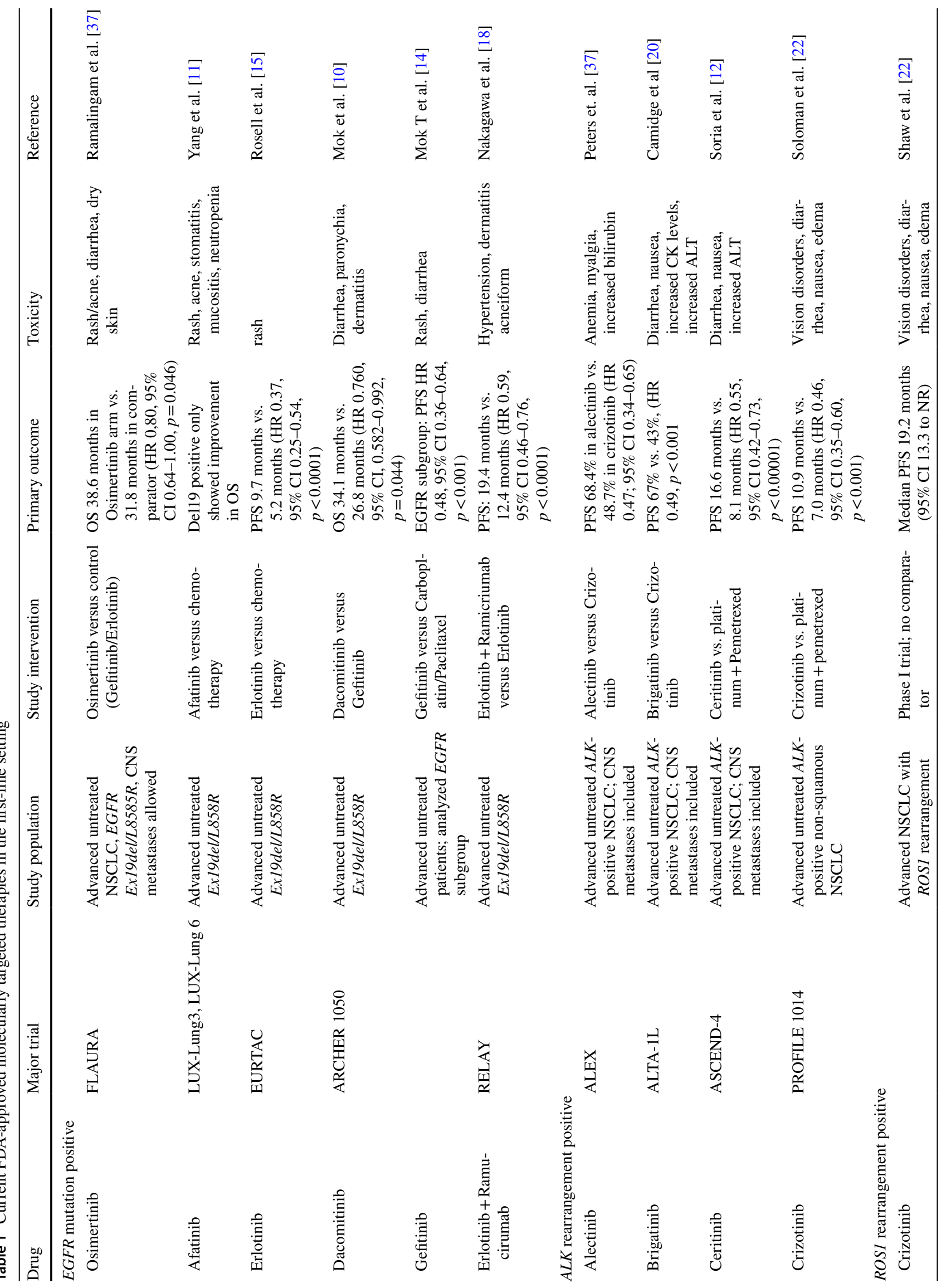




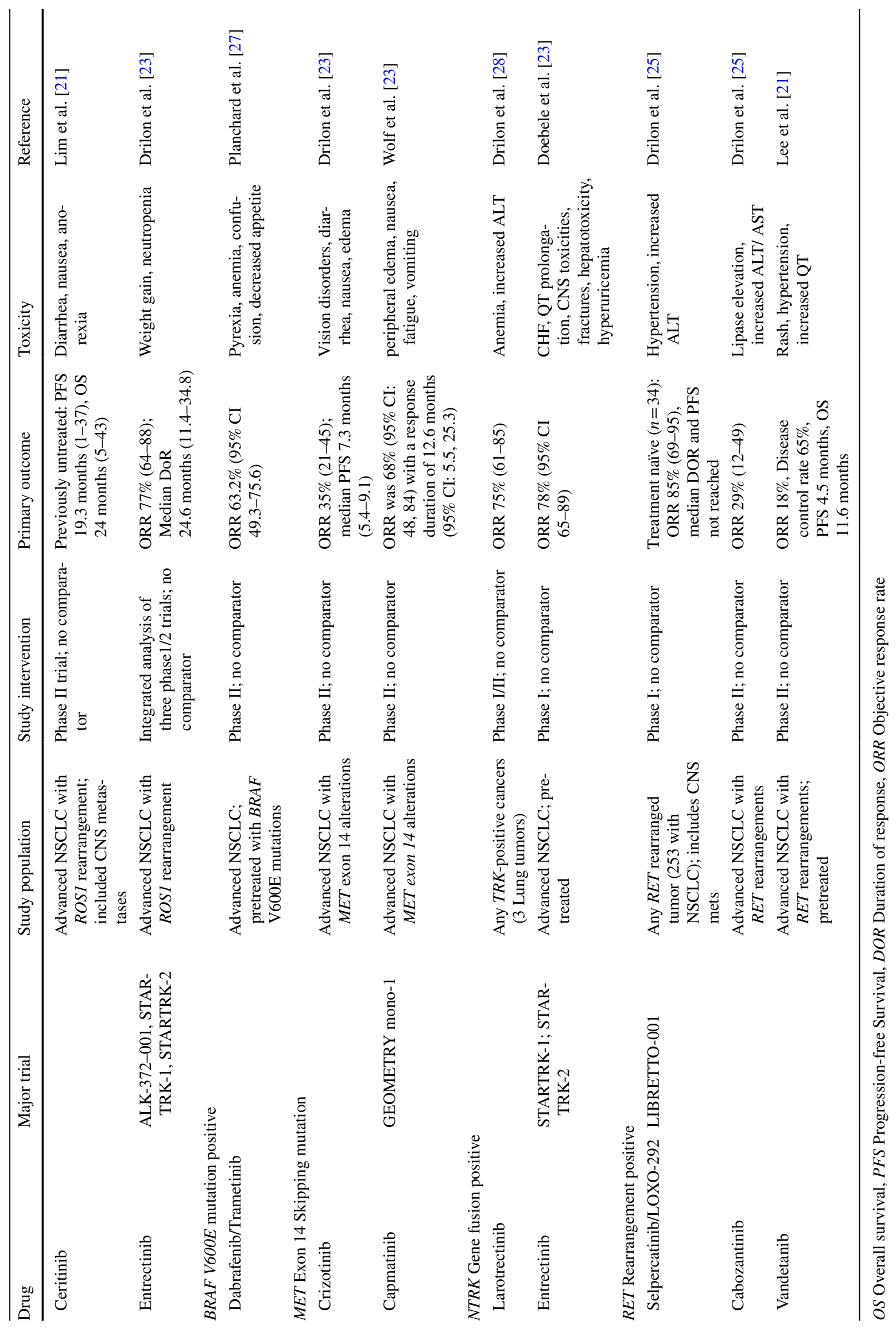


Another notable oncogenic driver with FDA-approved targeted therapy is $M E T$ exon 14 skipping mutation, which can occur in $2 \%-4 \%$ of NSCLC. The GEOMETRY mono- 1 trial showed that patients with metastatic NSCLC with confirmed MET exon 14 skipping mutation benefited from capmatinib in the first-line setting (ORR 68\% with a response duration of 12.6 months) [29]. Other options upon progression are crizotinib or cabozantinib.

\section{Principles of Immunotherapy (Either as Monotherapy or in Combination)}

Immunotherapy has demonstrated a survival benefit in patients with locally advanced NSCLC. In the PACIFIC trial, a phase III randomized trial comparing durvalumab and placebo as consolidation therapy given every 2 weeks up to 1 year in unresectable stage III NSCLC, patients who received anti-PD-L1, durvalumab after chemoradiation had a remarkable improvement in overall survival (median OS not reached in the durvalumab arm compared to 29.1 months with placebo [HR 0.69 (95\% CI 0.55-0.86)] [30, 31]

In patients with no targetable genetic alterations and no contraindications to PD-1/PD-L1 inhibitors, immunotherapy either as monotherapy or in combination has become the standard of care in the front-line setting for advanced squamous and non-squamous lung cancer (Table 2). The checkpoint inhibitors used in advanced NSCLC are the antiPD-1 pembrolizumab and nivolumab; anti-PD-L1 inhibitors atezolizumab; and the anti-CTLA4 inhibitor, ipilimumab.

Pembrolizumab demonstrated efficacy in KEYNOTE-024, a phase III randomized trial comparing single agent pembrolizumab against platinum chemotherapy in untreated stage IV NSCLC patients. In this trial, patients with tumors expressing PD-L1 tumor proportion score (TPS) $\geq 50 \%$ demonstrated superior response rate of pembrolizumab monotherapy over chemotherapy, $44.8 \%$ vs. $27.8 \%$, and superior overall survival, median OS 30.0 months (95\% CI 18.3 months-not reached) vs. 14.2 months (95\% CI 9.8 vs. 19.0 months) [32, 33]. The overall survival benefit of pembrolizumab monotherapy was also demonstrated in patients with PD-L1 TPS of $\geq 1 \%$ in KEYNOTE-042, a randomized phase III trial which demonstrated superior overall survival in untreated metastatic NSCLC patients receiving pembrolizumab compared to chemotherapy in patients with TPS $\geq 50 \%$, TPS $\geq 20 \%$, and TPS $\geq 1 \%$ [34]. In the exploratory analysis, overall survival of pembrolizumab was not statistically significant in patients with TPS $1 \%-49 \%$, which suggested that survival benefit in TPS $\geq 1 \%$ group was primarily driven by improved survival in patients with TPS $\geq 50 \%$ [34]. Atezolizumab was also demonstrated to have superior overall survival benefit in metastatic treatment naïve NSCLC patients with PD-L1 tumor cells $\geq 50 \%$ or tumor infiltrating immune cells $\geq 10 \%$, compared to chemotherapy by 7 months in the IMpower- 110 study [35]. Superior overall survival was also observed in patients with PD-L1 tumor cells $\geq 5 \%$ or tumor infiltrating immune cells $\geq 5 \%$ [35]. A newly approved chemotherapyfree option for patients with PD-L1 $\geq 1 \%$ is the combination immunotherapy, ipilimumab and nivolumab as seen in CHECKMATE-227 [36]. When compared to chemotherapy, the median OS was 17.1 months vs. 14.9 months (HR 0.79, 95\% CI 0.67-0.94, $p=0.0066$ ).

Most recently, front-line doublet immunotherapy with nivolumab and ipilimumab demonstrated improved overall survival benefit compared to chemotherapy alone. In the $\mathrm{PD}-\mathrm{L} 1 \geq 1 \%$ population, patients who received nivolumab and ipilimumab had median duration OS of 17.1 months (95\% CI 15-20.1) compared to 14.9 months (95\% CI 12.7-16.7) with chemotherapy alone [37]. Similar benefit in overall survival was observed in patients with PD-L $1<1 \%, 17.2$ months (95\% CI 12.8-22.0) in doublet immunotherapy compared to 12.2 months (95\% CI 9.2-14.3) in chemotherapy and nivolumab groups [37]. Grade 3 or 4 treatment-related adverse effects were comparable between the two groups, $32.8 \%$ in doublet immunotherapy compared to $36 \%$ in chemotherapy [37]. Although it was observed that patients with PD-L1 $<1 \%$ who received doublet immunotherapy had improved overall survival compared to patients who received combination chemoimmunotherapy with nivolumab, it is unknown whether doublet immunotherapy outperforms single agent nivolumab as the study was not powered to make such a comparison [37].

In patients with $\mathrm{PD}-\mathrm{L} 1<1 \%$, there are several combination chemoimmunotherapy options based on KEYNOTE-189, KEYNOTE-407, CHECKMATE-9LA, and IMpower-150 [38-40].

In KEYNOTE-189, a phase 3 trial, patients with nonsquamous NSCLC regardless of TPS were randomized to cisplatin or carboplatin plus pemetrexed with pembrolizumab or placebo followed by pemetrexed and pembrolizumab or placebo maintenance therapy [38]. Overall survival was superior in the chemoimmunotherapy group for all subgroups of TPS: TPS < 1\% (HR 0.59, 95\% CI 0.38-092), TPS $1-49 \%$ (HR $0.55,95 \%$ CI $0.34-0.90$ ), and TPS $\geq 50 \%$ (HR 0.42, CI 0.26-0.68) [38]. Similarly, improved overall survival of chemoimmunotherapy regardless of PD-L1 expression was demonstrated in patients with metastatic squamous NSCLC in KEYNOTE-407 [39]. Patients who received carboplatin and taxane-based therapy, either paclitaxel or nanoparticle albumin-bound (nab)-paclitaxel, in combination with pembrolizumab had improved overall survival, median OS 15.9 months (95\% CI 13.2-not reached), compared to chemotherapy and placebo, median OS 11.3 months (95\% CI 9.5-14.8) [39]. Patients with PD-L $1<1 \%$ by TPS also had improved OS, HR 0.61 (95\% CI 0.38-0.98) [39]. 


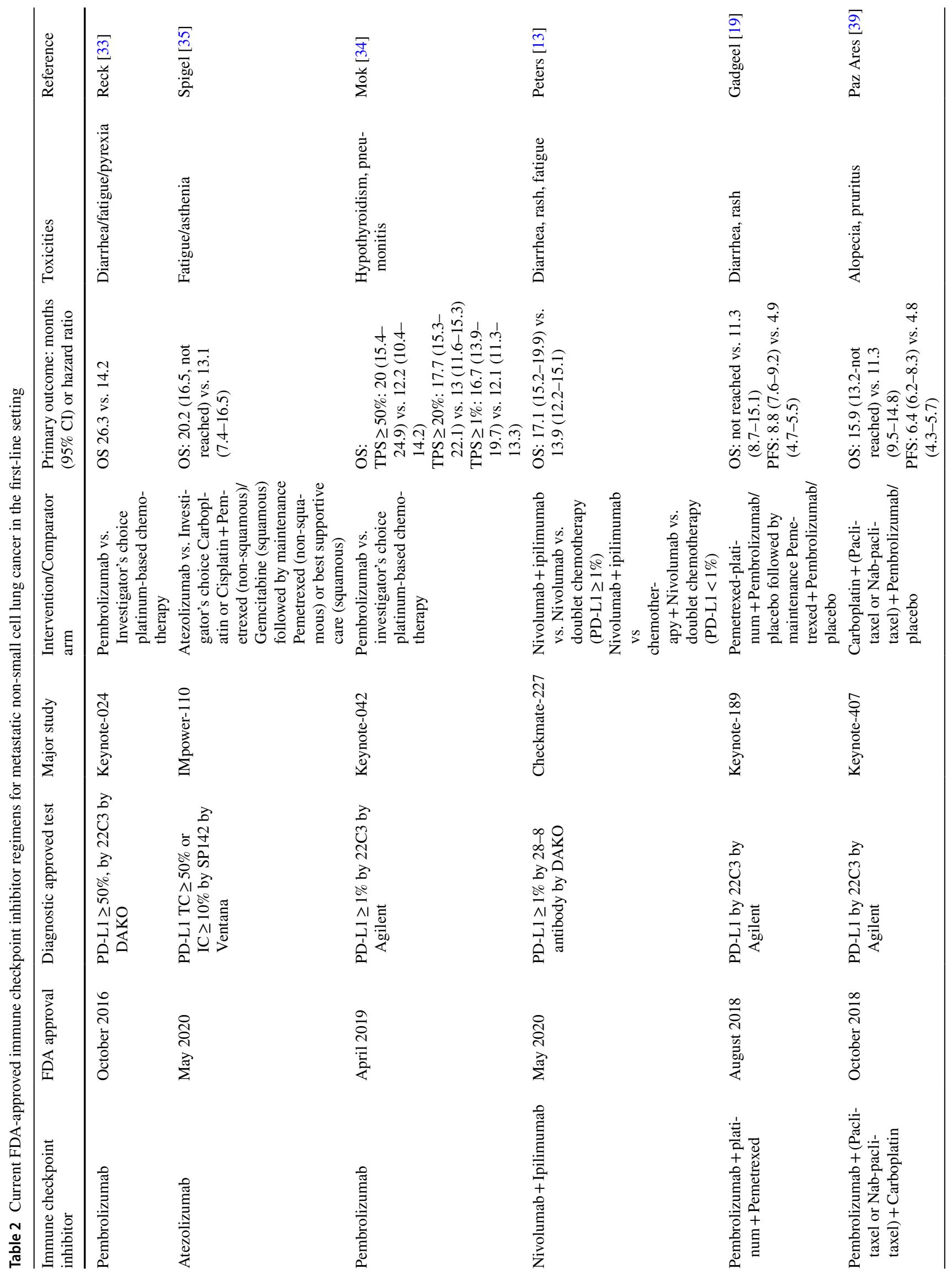


CHECKMATE-9LA randomized patients with advanced NSCLC that were treatment naive to combination immunotherapy, nivolumab plus ipilimumab and two cycles of platinum-doublet chemotherapy versus platinum-doublet chemotherapy [40]. Regardless of PD-L1 expression, the median OS was 14.1 months in the combination versus 10.7 months with chemotherapy alone (HR 0.69, 0.55-0.87).

IMpower-150 also demonstrated improved survival of chemoimmunotherapy in treatment naïve patients with advanced non-squamous NSCLC. Patients who received combination atezolizumab, bevacizumab, carboplatin, and paclitaxel (ABCP) had superior overall survival, median OS of 19.2 months, compared to bevacizumab, carboplatin, and paclitaxel alone (BCP), median OS of 14.7 months, HR 0.78 (95\% CI 0.64-0.96) [41]. Exploratory analysis also demonstrated improved OS of ABCP in patients with EGFR mutations, especially with sensitizing mutations, HR 0.31 (95\% CI 0.11-0.83), which suggests ABCP to be an option for patients with $E G F R$ mutation who fail initial tyrosine kinase inhibitor therapy [42]. Patients with liver metastasis had superior OS with $\mathrm{ABCP}$, where there was a $46 \%$ reduction in death compared to BCP (HR 0.54, 95\% CI 0.33-0.88) [43]. The improved PFS of ABCP was observed in all PD-L1 groups, including patients with PD-L1 expression less than $1 \%$ of in the tumor cells and/or tumor infiltrating cells, HR 0.77 (95\% CI 0.61-0.99), but the overall survival was not statistically significant among the PD-L1-negative group (HR 0.82, 95\% CI 0.62-1.08) [41, 43].

\section{Principles of Managing Immune-Related Adverse Effects}

Management of immune-related adverse effects is an integral part of immunotherapy. Toxicities can involve any organ system and commonly involves the skin, gastrointestinal tract, lung, thyroid, and pituitary gland. It can occur even after discontinuation of immunotherapy; thus careful monitoring of symptoms remains vital [44].

There are several general guidelines for the management of immunotherapy-related adverse effects [44]. Grade 1 toxicities are monitored without holding the medication. With grade 2 toxicities, immunotherapy is generally held until toxicity improves to grade 0 or grade 1 and treatment with $0.5-1 \mathrm{mg} / \mathrm{kg} /$ day of prednisone is begun. With grade 3 toxicities, higher dose of prednisone, $1-2 \mathrm{mg} / \mathrm{kg} /$ day or IV methylprednisolone $1-2 \mathrm{mg} / \mathrm{kg} /$ day is begun after discontinuation of immunotherapy. If symptoms do not improve after 3-5 days, next line of therapy includes infliximab or vedolizumab. Once toxicity improves to grade 1, patients may be re-challenged. With grade 4 toxicity, however, it is generally recommended that immunotherapy is discontinued permanently unless it is an endocrine immune toxicity that can be controlled with hormone replacement. More detailed 
information regarding specific adverse effect and recommended management has been described $[45,46]$.

\section{Conclusion}

Many revolutionary advances have recently been made in the management of NSCLC. First, in lung cancer screening, both National Lung Screening Trial and the NELSON trial have shown that low-dose CT screening can be effective in lowering lung cancer mortality rates. Second, immunotherapy is now at the forefront of treatment in oncogenic driver negative NSCLC. Immunotherapy continues to demonstrate a significant overall survival benefit in advanced NSCLC. As monotherapy, pembrolizumab or atezolizumab is superior to first-line chemotherapy in tumors with (high) positive PD-L1 expression. As combination approach, a number of chemo-immunotherapy combinations prove to be superior to chemotherapy, regardless of PD-L1 expression (keynote-189, keynote-407). Third, there have been a number of approvals of molecular-targeted therapy for subgroups of NSCLC patients with sensitizing EGFR, ALK, ROS1, RET, BRAF V600E, MET, or NTRK alterations.

\section{Compliance with Ethical Standards}

Conflict of interest Mariam Alexander and So Yeon Kim do not have any conflicts of interest to disclose. Haiying Cheng has received research funding from Genentech/Roche, Eisai, Spectrum, Regeneron, Bayer, and Vaccinex.

\section{References}

1. Siegel RL, Miller KD, Jemal A (2020) Cancer statistics, 2020. CA: Cancer J Clin 70(1):7-30. https://doi.org/10.3322/caac.21590

2. Couraud S, Zalcman G, Milleron B, Morin F, Souquet PJ (2012) Lung cancer in never smokers-a review. Eur J Cancer 48(9):1299_ 1311. https://doi.org/10.1016/j.ejca.2012.03.007

3. Tang MS, Wu XR, Lee HW, Xia Y, Deng FM, Moreira AL, Chen LC, Huang WC, Lepor H (2019) Electronic-cigarette smoke induces lung adenocarcinoma and bladder urothelial hyperplasia in mice. Proc Natl Acad Sci USA 116(43):21727-21731

4. de Koning HJ, van der Aalst CM, de Jong PA, Scholten ET, Nackaerts K, Heuvelmans MA, Lammers JJ, Weenink C, Yousaf-Khan U, Horeweg N, van 'tWesteinde S, Prokop M, Mali WP, Hoesein FAAM, van Ooijen PMA, Aerts J, den Bakker MA, Thunnissen E, Verschakelen J, Vliegenthart R, Walter JE, Ten Haaf K, Groen HJM, Oudkerk M (2020) Reduced lung-cancer mortality with volume CT screening in a randomized trial. New Engl J Med 382(6):503-513. https://doi.org/10.1056/NEJMoa1911793

5. Jemal A, Fedewa SA (2017) Lung cancer screening with lowdose computed tomography in the United States-2010 to 2015. JAMA Oncol 3(9):1278-1281. https://doi.org/10.1001/jamao ncol.2016.6416
6. Garassino MC, Whisenant JG, Huang LC, Trama A, Torri V, Agustoni F, Baena J, Banna G, Berardi R, Bettini AC, Bria E, Brighenti M, Cadranel J, De Toma A, Chini C, Cortellini A, Felip E, Finocchiaro G, Garrido P, Genova C, Giusti R, Gregorc V, Grossi F, Grosso F, Intagliata S, La Verde N, Liu SV, Mazieres J, Mercadante E, Michielin O, Minuti G, MoroSibilot D, Pasello G, Passaro A, Scotti V, Solli P, Stroppa E, Tiseo M, Viscardi G, Voltolini L, Wu YL, Zai S, Pancaldi V, Dingemans AM, Van Meerbeeck J, Barlesi F, Wakelee H, Peters S, Horn L (2020) COVID-19 in patients with thoracic malignancies (TERAVOLT): first results of an international, registrybased, cohort study. Lancet Oncol. https://doi.org/10.1016/ s1470-2045(20)30314-4

7. Shim J, Brindle L, Simon M, George S (2014) A systematic review of symptomatic diagnosis of lung cancer. Fam Pract 31(2):137-148. https://doi.org/10.1093/fampra/cmt076

8. Brierley JGM, Wittekind C (2017) TNM classification of malignant tumours, 8th edn. Wiley, NJ

9. Leighl NB, Page RD, Raymond VM, Daniel DB, Divers SG, Reckamp KL, Villalona-Calero MA, Dix D, Odegaard JI, Lanman RB, Papadimitrakopoulou VA (2019) Clinical utility of comprehensive cell-free DNA analysis to identify genomic biomarkers in patients with newly diagnosed metastatic non-small cell lung cancer. Clin Cancer Res 25(15):4691-4700. https://doi. org/10.1158/1078-0432.Ccr-19-0624

10. Rolfo C, Mack PC, Scagliotti GV, Baas P, Barlesi F, Bivona TG, Herbst RS, Mok TS, Peled N, Pirker R, Raez LE, Reck M, Riess JW, Sequist LV, Shepherd FA, Sholl LM, Tan DSW, Wakelee HA, Wistuba II, Wynes MW, Carbone DP, Hirsch FR, Gandara DR (2018) Liquid biopsy for advanced Non-Small Cell Lung Cancer (NSCLC): A statement paper from the IASLC. J Thorac Oncol 13(9):1248-1268. https://doi.org/10.1016/j.jtho.2018.05.030

11. Jenkins S, Yang JC, Ramalingam SS, Yu K, Patel S, Weston S, Hodge R, Cantarini M, Janne PA, Mitsudomi T, Goss GD (2017) Plasma ctDNA analysis for detection of the EGFR T790M mutation in patients with advanced non-small cell lung cancer. J Thorac Oncol 12(7):1061-1070. https://doi.org/10.1016/j. jtho.2017.04.003

12. Soria JC, Ohe Y, Vansteenkiste J, Reungwetwattana T, Chewaskulyong B, Lee KH, Dechaphunkul A, Imamura F, Nogami N, Kurata T, Okamoto I, Zhou C, Cho BC, Cheng Y, Cho EK, Voon PJ, Planchard D, Su WC, Gray JE, Lee SM, Hodge R, Marotti M, Rukazenkov Y, Ramalingam SS (2018) Osimertinib in untreated EGFR-mutated advanced non-small-cell lung cancer. New Engl J Med 378(2):113-125. https://doi.org/10.1056/NEJMoa1713137

13. Gadgeel SM, Mok TSK, Peters S, Alexander JAA, Leighl NB, Sriuranpong V, Perol M, De Castro G, Nadal E, De Marinis F, Han JY, Yan M, Riehl T, Schleifman E, Paul SM, Mocci S, Shames D, Mathisen MS, Dziadziuszko R (2019) LBA81_PR-Phase II/ III blood first assay screening trial (BFAST) in patients (pts) with treatment-naïve NSCLC: initial results from the ALK+ cohort. Ann Oncol 30:v918. https://doi.org/10.1093/annonc/mdz394.079

14. Gandara DR, Paul SM, Kowanetz M, Schleifman E, Zou W, Li Y, Rittmeyer A, Fehrenbacher L, Otto G, Malboeuf C, Lieber DS, Lipson D, Silterra J, Amler L, Riehl T, Cummings CA, Hegde PS, Sandler A, Ballinger M, Fabrizio D, Mok T, Shames DS (2018) Blood-based tumor mutational burden as a predictor of clinical benefit in non-small-cell lung cancer patients treated with atezolizumab. Nat Med 24(9):1441-1448. https://doi.org/10.1038/s4159 1-018-0134-3

15. Pignon JP, Tribodet H, Scagliotti GV, Douillard JY, Shepherd FA, Stephens RJ, Dunant A, Torri V, Rosell R, Seymour L, Spiro SG, Rolland E, Fossati R, Aubert D, Ding K, Waller D, Le Chevalier $\mathrm{T}$ (2008) Lung adjuvant cisplatin evaluation: a pooled analysis by the LACE Collaborative Group. J Clin Oncol 26(21):3552-3559. https://doi.org/10.1200/jco.2007.13.9030 
16. Midha A, Dearden S, McCormack R (2015) EGFR mutation incidence in non-small-cell lung cancer of adenocarcinoma histology: a systematic review and global map by ethnicity (mutMapII). Am J Cancer Res 5(9):2892-2911

17. Ramalingam SS, Vansteenkiste J, Planchard D, Cho BC, Gray JE, Ohe Y, Zhou C, Reungwetwattana T, Cheng Y, Chewaskulyong B, Shah R, Cobo M, Lee KH, Cheema P, Tiseo M, John T, Lin MC, Imamura F, Kurata T, Todd A, Hodge R, Saggese M, Rukazenkov Y, Soria JC (2020) Overall survival with osimertinib in untreated, EGFR-mutated advanced NSCLC. New Engl J Med 382(1):41-50. https://doi.org/10.1056/NEJMoa1913662

18. Nakagawa K, Garon EB, Seto T, Nishio M, Ponce Aix S, PazAres L, Chiu CH, Park K, Novello S, Nadal E, Imamura F, Yoh K, Shih JY, Au KH, Moro-Sibilot D, Enatsu S, Zimmermann A, Frimodt-Moller B, Visseren-Grul C, Reck M (2019) Ramucirumab plus erlotinib in patients with untreated, EGFR-mutated, advanced non-small-cell lung cancer (RELAY): a randomised, double-blind, placebo-controlled, phase 3 trial. Lancet Oncol 20(12):1655-1669. https://doi.org/10.1016/s1470-2045(19)30634 $-5$

19. Camidge DR, Dziadziuszko R, Peters S, Mok T, Noe J, Nowicka M, Gadgeel SM, Cheema P, Pavlakis N, de Marinis F, Cho BC, Zhang L, Moro-Sibilot D, Liu T, Bordogna W, Balas B, Muller B, Shaw AT (2019) Updated efficacy and safety data and impact of the EML4-ALK fusion variant on the efficacy of alectinib in untreated ALK-positive advanced non-small cell lung cancer in the global phase III ALEX Study. J Thorac Oncol 14(7):12331243. https://doi.org/10.1016/j.jtho.2019.03.007

20. Camidge R HRK, M. Ahn3, J.C. Yang4, J. Han5, M.J. Hochmair6, K.H. Lee7, A. Delmonte8, M.R. Garcia Campelo9, D. Kim10, F. Griesinger11, E. Felip12, R. Califano13, A. Spira14, S. Gettinger15, M. Tiseo16, Q. Ni17, P. Zhang18, S. Popat19 (2019) Brigatinib vs crizotinib in patients with ALK inhibitor-naive advanced ALK+ NSCLC: Updated results from the phase III ALTA-1L trial. ESMO Asia Congress 2019 Presented November 23, 2019

21. Lim SM, Kim HR, Lee J-S, Lee KH, Lee Y-G, Min YJ, Cho EK, Lee SS, Kim B-S, Choi MY, Shim HS, Chung J-H, La Choi Y, Lee MJ, Kim M, Kim J-H, Ali SM, Ahn M-J, Cho BC (2017) Open-label, multicenter, phase II study of ceritinib in patients with non-small-cell lung cancer harboring ROS1 rearrangement. J Clin Oncol 35(23):2613-2618. https://doi.org/10.1200/ JCO.2016.71.3701

22. Shaw AT, Riely GJ, Bang YJ, Kim DW, Camidge DR, Solomon BJ, Varella-Garcia M, Iafrate AJ, Shapiro GI, Usari T, Wang SC, Wilner KD, Clark JW, Ou SI (2019) Crizotinib in ROS1-rearranged advanced non-small-cell lung cancer (NSCLC): updated results, including overall survival, from PROFILE 1001. Ann Oncol 30(7):1121-1126. https://doi.org/10.1093/annonc/mdz131

23. Drilon A, Siena S, Dziadziuszko R, Barlesi F, Krebs MG, Shaw AT, de Braud F, Rolfo C, Ahn MJ, Wolf J, Seto T, Cho BC, Patel MR, Chiu CH, John T, Goto K, Karapetis CS, Arkenau HT, Kim SW, Ohe Y, Li YC, Chae YK, Chung CH, Otterson GA, Murakami H, Lin CC, Tan DSW, Prenen H, Riehl T, Chow-Maneval E, Simmons B, Cui N, Johnson A, Eng S, Wilson TR, Doebele RC (2020) Entrectinib in ROS1 fusion-positive non-small-cell lung cancer: integrated analysis of three phase 1-2 trials. Lancet Oncol 21(2):261-270. https://doi.org/10.1016/s1470-2045(19)30690-4

24. Shaw AT, Solomon BJ, Chiari R, Riely GJ, Besse B, Soo RA, Kao S, Lin CC, Bauer TM, Clancy JS, Thurm H, Martini JF, Peltz G, Abbattista A, Li S, Ou SI (2019) Lorlatinib in advanced ROS1positive non-small-cell lung cancer: a multicentre, open-label, single-arm, phase 1-2 trial. Lancet Oncol 20(12):1691-1701. https://doi.org/10.1016/s1470-2045(19)30655-2

25. Drilon A, Oxnard G, Wirth L, Besse B, Gautschi O, Tan SWD, Loong H, Bauer T, Kim YJ, Horiike A, Park K, Shah M, McCoach
C, Bazhenova L, Seto T, Brose M, Pennell N, Weiss J, Matos I, Peled N, Cho BC, Ohe Y, Reckamp K, Boni V, Satouchi M, Falchook G, Akerley W, Daga H, Sakamoto T, Patel J, Lakhani N, Barlesi F, Burkard M, Zhu V, Moreno Garcia V, Medioni J, Matrana M, Rolfo C, Lee DH, Nechushtan H, Johnson M, Velcheti V, Nishio M, Toyozawa R, Ohashi K, Song L, Han J, Spira A, De Braud F, Staal Rohrberg K, Takeuchi S, Sakakibara J, Waqar S, Kenmotsu H, Wilson F, Nair B, Olek E, Kherani J, Ebata K, Zhu E, Nguyen M, Yang L, Huang X, Cruickshank S, Rothenberg S, Solomon B, Goto K, Subbiah V (2019) PL02.08 registrational results of LIBRETTO-001: a phase 1/2 trial of LOXO-292 in patients with RET fusion-positive lung cancers. J Thorac Oncol 14(10):S6-S7. https://doi.org/10.1016/j.jtho.2019.08.059

26. Drilon A, Rekhtman N, Arcila M, Wang L, Ni A, Albano M, Van Voorthuysen M, Somwar R, Smith RS, Montecalvo J, Plodkowski A, Ginsberg MS, Riely GJ, Rudin CM, Ladanyi M, Kris MG (2016) Cabozantinib in patients with advanced RET-rearranged non-small-cell lung cancer: an open-label, single-centre, phase 2, single-arm trial. Lancet Oncol 17(12):1653-1660. https://doi. org/10.1016/s1470-2045(16)30562-9

27. Planchard D, Besse B, Groen HJM, Souquet PJ, Quoix E, Baik CS, Barlesi F, Kim TM, Mazieres J, Novello S, Rigas JR, Upalawanna A, D'Amelio AM Jr, Zhang P, Mookerjee B, Johnson BE (2016) Dabrafenib plus trametinib in patients with previously treated BRAF(V600E)-mutant metastatic non-small cell lung cancer: an open-label, multicentre phase 2 trial. Lancet Oncol 17(7):984-993. https://doi.org/10.1016/s1470-2045(16)30146-2

28. Drilon A, Laetsch TW, Kummar S, DuBois SG, Lassen UN, Demetri GD, Nathenson M, Doebele RC, Farago AF, Pappo AS, Turpin B, Dowlati A, Brose MS, Mascarenhas L, Federman N, Berlin J, El-Deiry WS, Baik C, Deeken J, Boni V, Nagasubramanian R, Taylor M, Rudzinski ER, Meric-Bernstam F, Sohal DPS, Ma PC, Raez LE, Hechtman JF, Benayed R, Ladanyi M, Tuch BB, Ebata K, Cruickshank S, Ku NC, Cox MC, Hawkins DS, Hong DS, Hyman DM (2018) Efficacy of larotrectinib in TRK fusion-positive cancers in adults and children. New Engl J Med 378(8):731-739. https://doi.org/10.1056/NEJMoa1714448

29. Garon EB RSH, Takashi Seto, Ji-Youn Han, Noemi Reguart, Harry J. M. Groen, Daniel SW Tan, Toyoaki Hida, Maja J. A. De Jonge, Sergey V. Orlov, Egbert F. Smit, Pierre-Jean Souquet, Johan Vansteenkiste, Sylvie Le Mouhaer, Anna Robeva, Maeve Waldron-Lynch, Monica Giovannini, Juergen Wolf. (2020) CT082 - Capmatinib in METex 14-mutated (mut) advanced non-small cell lung cancer (NSCLC): Results from the phase II GEOMETRY mono-1 study, including efficacy in patients (pts) with brain metastases (BM). (Proceedings of the AACR Virtual Annual Meeting II: June 22-24, 2020)

30. Gray JE, Villegas A, Daniel D, Vicente D, Murakami S, Hui R, Kurata T, Chiappori A, Lee KH, Cho BC, Planchard D, Paz-Ares L, Faivre-Finn C, Vansteenkiste JF, Spigel DR, Wadsworth C, Taboada M, Dennis PA, Özgüroğlu M, Antonia SJ (2020) Threeyear overall survival with durvalumab after chemoradiotherapy in stage III NSCLC-update from PACIFIC. J Thorac Oncol 15(2):288-293. https://doi.org/10.1016/j.jtho.2019.10.002

31. Antonia SJ, Villegas A, Daniel D, Vicente D, Murakami S, Hui R, Yokoi T, Chiappori A, Lee KH, de Wit M, Cho BC, Bourhaba M, Quantin X, Tokito T, Mekhail T, Planchard D, Kim Y-C, Karapetis CS, Hiret S, Ostoros G, Kubota K, Gray JE, Paz-Ares L, de Castro CJ, Wadsworth C, Melillo G, Jiang H, Huang Y, Dennis PA, Özgüroğlu M (2017) Durvalumab after chemoradiotherapy in stage III non-small-cell lung cancer. N Engl J Med 377(20):1919_ 1929. https://doi.org/10.1056/NEJMoa1709937

32. Reck M, Rodriguez-Abreu D, Robinson AG, Hui R, Csoszi T, Fulop A, Gottfried M, Peled N, Tafreshi A, Cuffe S, O’Brien M, Rao S, Hotta K, Leiby MA, Lubiniecki GM, Shentu Y, Rangwala R, Brahmer JR (2016) Pembrolizumab versus chemotherapy 
for PD-L1-positive non-small-cell lung cancer. New Engl J Med 375(19):1823-1833. https://doi.org/10.1056/NEJMoa1606774

33. Reck M, Rodriguez-Abreu D, Robinson AG, Hui R, Csoszi T, Fulop A, Gottfried M, Peled N, Tafreshi A, Cuffe S, O'Brien M, Rao S, Hotta K, Vandormael K, Riccio A, Yang J, Pietanza MC, Brahmer JR (2019) Updated analysis of KEYNOTE-024: pembrolizumab versus platinum-based chemotherapy for advanced non-small-cell lung cancer with PD-L1 tumor proportion score of 50\% or greater. J Clin Oncol 37(7):537-546. https://doi. org/10.1200/jco.18.00149

34. Mok TSK, Wu YL, Kudaba I, Kowalski DM, Cho BC, Turna HZ, Castro G Jr, Srimuninnimit V, Laktionov KK, Bondarenko I, Kubota K, Lubiniecki GM, Zhang J, Kush D, Lopes G, Investigators K (2019) Pembrolizumab versus chemotherapy for previously untreated, PD-L1-expressing, locally advanced or metastatic nonsmall-cell lung cancer (KEYNOTE-042): a randomised, openlabel, controlled, phase 3 trial. Lancet 393(10183):1819-1830. https://doi.org/10.1016/S0140-6736(18)32409-7

35. Spigel D, Giaccone G, Reinmuth N, Vergnenegre A, Barrios CH, Morise M, Felip E, Andric ZG, Geater S, Özgüroğl M, Mocci S, McCleland M, Enquist I, Komatsubara KM, Deng Y, Kuriki H, Wen X, Jassem J, Herbst RS (2019) IMpower110: Interim overall survival (OS) analysis of a Phase III study of atezolizumab (atezo) vs platinum-based chemotherapy (chemo) as first-line (1L) treatment (tx) in PD-L1-selected NSCLC. Ann Oncol 30:v851-v934

36. Peters S RS, Paz-Ares L, et al. (2019) Nivolumab + low-dose ipilimumab versus platinum-doublet chemotherapy as first-line treatment for advanced non-small cell lung cancer: CheckMate-227 part 1 final analysis. Presented at: 2019 ESMO Congress; September 27 to October 1, 2019; Barcelona, Spain Abstract LBA4

37. Hellmann MD, Paz-Ares L, Bernabe Caro R, Zurawski B, Kim SW, Carcereny Costa E, Park K, Alexandru A, Lupinacci L, de la Mora JE, Sakai H, Albert I, Vergnenegre A, Peters S, Syrigos K, Barlesi F, Reck M, Borghaei H, Brahmer JR, O'Byrne KJ, Geese WJ, Bhagavatheeswaran P, Rabindran SK, Kasinathan RS, Nathan FE, Ramalingam SS (2019) Nivolumab plus Ipilimumab in advanced non-small-cell lung cancer. N Engl J Med 381(21):2020-2031. https://doi.org/10.1056/NEJMoa1910231

38. Gandhi L, Rodriguez-Abreu D, Gadgeel S, Esteban E, Felip E, De Angelis F, Domine M, Clingan P, Hochmair MJ, Powell SF, Cheng SY, Bischoff HG, Peled N, Grossi F, Jennens RR, Reck M, Hui R, Garon EB, Boyer M, Rubio-Viqueira B, Novello S, Kurata T, Gray JE, Vida J, Wei Z, Yang J, Raftopoulos H, Pietanza MC, Garassino MC (2018) Pembrolizumab plus chemotherapy in metastatic non-small-cell lung cancer. New Engl J Med 378(22):20782092. https://doi.org/10.1056/NEJMoa1801005

39. Paz-Ares L, Luft A, Vicente D, Tafreshi A, Gumus M, Mazieres J, Hermes B, Cay Senler F, Csoszi T, Fulop A, Rodriguez-Cid J, Wilson J, Sugawara S, Kato T, Lee KH, Cheng Y, Novello S, Halmos B, Li X, Lubiniecki GM, Piperdi B, Kowalski DM (2018) Pembrolizumab plus Chemotherapy for Squamous Non-SmallCell Lung Cancer. N Engl J Med 379(21):2040-2051. https://doi. org/10.1056/NEJMoa1810865

40. Reck M, Ciuleanu T-E, Dols MC, Schenker M, Zurawski B, Menezes J, Richardet E, Bennouna J, Felip E, Juan-Vidal O, Alexandru A, Sakai H, Scherpereel A, Lu S, John T, Carbone DP,
Meadows-Shropshire S, Yan J, LG P-A (2020) Nivolumab (NIVO) + ipilimumab (IPI) +2 cycles of platinum-doublet chemotherapy (chemo) vs 4 cycles chemo as first-line (1L) treatment (tx) for stage IV/recurrent non-small cell lung cancer (NSCLC): CheckMate 9LA. J Clin Oncol. 38:9501

41. Socinski MA, Jotte RM, Cappuzzo F, Orlandi F, Stroyakovskiy D, Nogami N, Rodriguez-Abreu D, Moro-Sibilot D, Thomas CA, Barlesi F, Finley G, Kelsch C, Lee A, Coleman S, Deng Y, Shen Y, Kowanetz M, Lopez-Chavez A, Sandler A, Reck M (2018) Atezolizumab for first-line treatment of metastatic nonsquamous NSCLC. New Engl J Med 378(24):2288-2301. https://doi. org/10.1056/NEJMoa1716948

42. Reck M, Mok TSK, Nishio M, Jotte RM, Cappuzzo F, Orlandi F, Stroyakovskiy D, Nogami N, Rodriguez-Abreu D, Moro-Sibilot D, Thomas CA, Barlesi F, Finley G, Lee A, Coleman S, Deng Y, Kowanetz M, Shankar G, Lin W, Socinski MA (2019) Atezolizumab plus bevacizumab and chemotherapy in non-small-cell lung cancer (IMpower150): key subgroup analyses of patients with EGFR mutations or baseline liver metastases in a randomised, open-label phase 3 trial. Lancet Respir Med 7(5):387401. https://doi.org/10.1016/s2213-2600(19)30084-0

43. Socinski MA, Jotte RM, Cappuzzo F, Orlandi FJ, Stroyakovskiy D, Nogami N, Rodriguez-Abreu D, Moro-Sibilot D, Thomas CA, Barlesi F, Finley GG, Kelsch C, Lee A, Coleman S, Shen Y, Kowanetz M, Lopez-Chavez A, Sandler A, Reck M (2018) Overall survival (OS) analysis of IMpower150, a randomized $\mathrm{Ph} 3$ study of atezolizumab (atezo) + chemotherapy (chemo) \pm bevacizumab (bev) vs chemo + bev in $1 \mathrm{~L}$ nonsquamous (NSQ) NSCLC. J Clin Oncol 36(15):9002-9002. https://doi.org/10.1200/ JCO.2018.36.15_suppl.9002

44. Brahmer JR, Lacchetti C, Thompson JA (2018) Management of immune-related adverse events in patients treated with immune checkpoint inhibitor therapy: American Society of Clinical Oncology Clinical Practice Guideline Summary. J Oncol Pract 14(4):247-249. https://doi.org/10.1200/jop.18.00005

45. Brahmer JR, Lacchetti C, Schneider BJ, Atkins MB, Brassil KJ, Caterino JM, Chau I, Ernstoff MS, Gardner JM, Ginex P, Hallmeyer S, Holter Chakrabarty J, Leighl NB, Mammen JS, McDermott DF, Naing A, Nastoupil LJ, Phillips T, Porter LD, Puzanov I, Reichner CA, Santomasso BD, Seigel C, Spira A, Suarez-Almazor ME, Wang Y, Weber JS, Wolchok JD, Thompson JA (2018) Management of immune-related adverse events in patients treated with immune checkpoint inhibitor therapy: American Society of Clinical Oncology Clinical Practice Guideline. J Clin Oncol 36(17):1714-1768

46. National Comprehensive Cancer Network. NCCN Clinical Practice Guidelines in Oncology, Management of ImmunotherapyRelated Toxicities (version 1.2020). Available online: https:// wwwnccnorg/professionals/physician_gls/pdf/immunotherapypdf

Publisher's Note Springer Nature remains neutral with regard to jurisdictional claims in published maps and institutional affiliations. 